\title{
Peirce's Concept of Signs and Kindergarten Literacy
}

\author{
Cynthia B. Leung \\ University of South Florida St. Petersburg \\ St. Petersburg, Florida, USA
}

\begin{abstract}
This article focuses on Peirce's writings about his concept of triadic sign relationships and applies his theory to analyses of multimodal literacy events in a kindergarten classroom where the author was a participant observer. Examples are provided to explain Peirce's descriptions of the elements of sign relationships - object, representamen, and interpretant. Peirce's theories are used to understand how the kindergarten children and their teacher make meaning from the children's multimodal writing productions. Possible objects and interpretants of the children's multimodal writings are explored. Figures of the children's drawings/writings and diagrams of relationships among sign elements in the kindergarten classroom are included in the paper.
\end{abstract}

Keywords: semiotics; kindergarten; multimodal literacy; early literacy; writing.

\section{Introduction}

Literacy events in preschool and kindergarten classrooms are multimodal, involving various modes of communication. Research on emergent literacy in the 1980s and 1990s first revealed the multimodal forms of expression used by children as they participate in literate acts and the importance of the social environment on literacy learning (e.g., Calkins, 1980; Dyson, 1982a, 1982b; Rowe, 1994; Sulzby, 1985a, 1985b; Sulzby, Barnhart \& Hieshima, 1989). From this research we learned that children's drawings are early forms of writing and their labeling of pictures and retelling stories by looking at illustrations are early forms of reading. More recent research has shown how children make meaning using various technologies along with more traditional forms of expression (e.g., Kim \& Kim 2017; Winters \& Vratulis, 2013; Zhang, Djonov, \& Toor, 2016).

In literature-rich classrooms, teachers read aloud storybooks to children, lead the class in phonemic awareness activities including rhyming games and reciting nursery rhymes, encourage children to use invented spelling to write in journals, write stories dictated by the children, and introduce activities involving iPads 
and online eBooks. Alphabet letters, drawings, illustrations, gestures, building blocks, numbers, graphs, songs, spoken words, printed words, and other types of signs come together during literacy events as teachers encourage young children to use familiar modes of expression from their homes and communities to learn about written language.

A sign can be defined as "something that stands for something else" (Colapietro, 1993, p. 179). Signs are objects, ideas, and events of everyday life, including life in schools, that we "use to represent the world around us and to make messages about it" (Danesi, 1993, p.1). Semiotics is the study of signs - the types of signs, the ways signs operate in different cultures, and the codes that organize the use of signs (Danesi, 1993). Semiotics provides a way to understand how children and their teachers make meaning from multimodal classroom events. Charles Peirce's concept of sign activity is particularly useful in analyses of classroom interactions because his model "recognize[s] the unlimited variety of forms" that can be "elements of dynamic signifying relationships" (Whitson, 1997, p. 100). As defined by Peirce, a sign, or representamen, can be

"an existent thing or actual fact ... a "word," a mere possible form to which an audible sound, visible shape, or other sensible object may conform to, or ... a property or habit of behavior of something either experienced or imagined." (Whitson, 1997, p. 6 [quoted from Peirce, 1909, 3, p. 233, New Elements of Mathematics]).

Thus, signs can be words, visual images, physical objects, behaviors, ideas, or concepts. All elements of the sign relationship as conceived by Peirce - object, representamen, and interpretant - can exist in any of these forms.

A Peircean semiotic perspective makes it possible to explore multimodal literacy learning in its full complexity in and outside of classrooms. Literacy learning is not reduced to just one of its components, such as written or spoken words, but can include visual images, digital representations, student and teacher thoughts and behaviors, and social interactions that occur during the use of various signs. In this article I examine Peirce's concept of signs and the triadic sign relationship and show how these concepts can be applied to the study of literacy learning and teaching in classroom contexts. I focus on applying the theories to sign relationships I observed and experienced during the course of a yearlong qualitative case study of a kindergarten classroom where I was a participant observer. Peirce's concept of triadic sign relationships is especially applicable in analyzing kindergarten literacy learning since literacy activities for young children involve different types of signs - visual, linguistic, and behavioral - and teachers and their students may interpret the signs differently.

\section{Peirce's Concept of Triadic Sign Relations}

Peirce believed that all thought is structured in signs; therefore, the study of signs is at the center of all inquiry (Brent, 1993). He saw semiotics as a way to make meaning or a path towards knowledge. In "Logic as Semiotic: The Theory of Signs," Peirce (1955) defined his conception of the elements of a sign relationship. 
"A sign, or representamen, is something which stands to somebody for something in some respect or capacity. It addresses somebody, that is, it creates in the mind of that person an equivalent sign, or perhaps a more developed sign. That sign which it creates I call the interpretant of that first sign. The sign stands for something, its object. It stands for that object, not in all respects, but in reference to a sort of idea, which I have sometimes called the ground of the representamen." (p. 99).

The object, representamen, and interpretant form a triadic relationship. The object can be an actual object, but it can also be an idea, a behavior, a word, a visual image, a feeling, a policy, or other cultural expression. This object can be represented by a sign or representamen. For example, think of the object as a cat, an actual animal. A kindergarten child may draw a picture of a cat or copy the letters C, A, T from the board or from an index card. The child may also tell a story about a cat. The picture of the cat, the letters CAT, and the story about the cat are all representations of the living cat. These representations are representamena or signs.

In manuscript notes "On Representations" written in 1873, Peirce further noted that "a representation is an object which stands for another, so that an experience of the former [the representamen] affords us the knowledge of another [the object]" (Peirce, 1986b, p. 65). He identified three essential characteristics of representations. They must 1) "have qualities independent of its meaning," 2) have "a real connection with its object," and 3) "appeal to some mind" (pp. 65-66). The ground is the character or abstract quality of a sign that makes it possible for that sign to represent a particular object. If we think of the kindergarten child's writing, we can see, for example, that the letters CAT are written in blue marker on the back of white unlined scrap paper. These are the independent qualities of the sign as a written word. Peirce also referred to these independent qualities as "material qualities of the representation" (p. 65). The physical properties of the cat determined the color orange the child used to draw and color his cat. This shows the "real" connection of the picture of the cat to the cat itself. The child's picture excites in his mind the image of the cat he left at home as he went to school that morning. When viewed by his classmates, the cat picture reminds another child of her cat at home. All of the forms of expression used by children in the kindergarten class that result in the creation of signs ultimately refer back to the object initially being represented.

Peirce deduced that there were three types of representations - icon, index, and symbol. An icon has the form or characteristics of its object, for example, a photograph, painting, statue, map, diagram, metaphor, or algebraic equation. With an index "there is some causal or natural connection or other between the sign and its object" (Merrell, 1995, p. 84). A thermometer is an index of body or room temperature, and lightning is an index of thunder. Signals and symptoms are also examples of indices. Symbolic signs can have a mental or intellectual connection to their object. Signification occurs through an association of ideas or a repeated or habitual connection between the object and the sign. Linguistic signs are symbolic. Representations that use oral or written language, including words, sentences, and narratives, are symbolic; however, written language can also be iconic as in ancient Chinese characters that resemble the things they 
represent, such as the characters for mountain, sun, and eye.

The relationship between the object and the representamen is similar to Saussure's concept of signified (the object) and signifier (signs); however, Peirce adds another level to this dyadic relationship with his notion of the interpretant (Whitson, 1997). The interpretant is actually another sign, the sign that is used to make meaning of the representamen in the mind of the person encountering that representamen. In the example of the kindergarten child's representations, various interpretants are possible. One interpretant could be sharing knowledge of the existence of the child's pet with the teacher or other classmates. Another interpretant could be the teacher's evaluation of the child's cognitive or literacy development by viewing or experiencing the sign created by the child. A third interpretant could be a story told by another child who viewed the picture or word, or heard the story told by the first child. The interpretant is the meaning given to the representamen, an interpretation of the sign, or the effect of the sign on the interpreter, such as an action taken after encountering the sign.

The representamen represents the object. In order for this relationship to be understood, however, it must be transformed into thought in the interpreter's mind. The object and the relationship between the object and its sign cannot be understood without the interpretant - the meaning it is given by the interpreter or the action taken by the interpreter in response to understanding the relationship. The role of the interpretant is to connect the representamen, or sign, to "something already known" and, in so doing, to "generate meaning" (Siegel, 1984, p. 43).

"Something becomes a representation by virtue of someone claiming that it stands for something. Meaning is not inherent in the form, but attributed by further representations about the form. That is, representational status is attributed by an observer." (Clancy \& Roschelle, 1991, p. 9)

One cannot make meaning from a sign without using another sign to express the original representation. The interpretant is a part of two processes of making meaning. First, it is a sign that mediates the relationship between the object and the representamen, and second, it is a sign that the representamen gives rise to in order to explain that representamen (Siegel, 1984; Buczynska-Garewicz, 1981). "The interpretant is the meaning of a sign and also another sign explaining the former one" (Buczynska-Garewicz, 1981, p. 192). Both the representamen and the interpretant are signs and represent the same object, but to "different degrees of specificity" (Parmentier, 1985, p. 27).

As the semiotic process unfolds, the original object and representamen become a new ground or object and the interpretant becomes the representamen for a new semiotic relationship. This semiotic process is an "endless series" (Peirce manuscript as quoted in Parmentier, 1985, p. 29). Since the interpretant can only be explained by using another sign, that interpretant becomes the sign of a new triadic relationship. Eco (1976) explained Peirce's conception of interpretants in the following way: "In order to establish what the interpretant of a sign is, it is necessary to name it by means of another sign which in turn has another 
interpretant to be named by another sign and so on" (p. 68). The process of making meaning from signs, then, is essentially unlimited since signs generate other signs.

\section{Semiotic Theories Applied to Literacy Research}

Literacy researchers have used semiotic theories to explain classroom activities. Siegel (1984), who studied reading and drawing as semiotic processes, observed the evolution of signs in the drawings of children in a fourth-grade class. One sign that recurred in children's drawings was an image of zigzag lines that looked like a bolt of lightning. These lines stood for "radiation." At first the children used zigzag lines to mean "radiation by some electricity" (p. 299). Then the meaning of the sign evolved, and the radiation lines indicated that a character was being punished for breaking some social code, such as being a bully or picking grapes where a sign says "Don't Pick." Over time, the zigzag lines came to signify friendship and were a collective comment on the mutual participation of a particular group of students. Thus, the interpretant, or meaning that was given to the zigzag lines, evolved in the social context of class sketching.

Golden and Gerber's (1990) semiotic analysis of picture storybook events revealed the complexity of these classroom activities. They described the picture book as "a unique kind of symbol in that meaning is generated simultaneously from verbal and visual cues...with each system complementing the other" (p. 207). Performance cues and instructional cues provided by the teacher as she reads the picture book aloud add to the types of signs involved in the creation of a read-aloud event. Golden and Gerber (1990) saw the object of the sign relationship as the sequence of events in the fictional or non-fictional world of the story. The representamena are a complex combination of the author's written text, the illustrator's visual text, and the teacher's oral text which includes performance cues, such as intonation, stress, and rhythm, and instructional cues, such as questions or talk about text. The interpretant is the version of the narrative that the listeners and the reader take away from the picture book performance.

Also, the social context of the reading influences the development of the interpretant. Different readings of a single picture book can involve different representamena, which in turn result in different interpretants in the minds of the participants.

"A picture book narrative...has the potential of generating multiple interpretations depending upon what the symbol offers, what the reader brings, and how the text is mediated by participants in a social context." (Golden $\mathcal{E}$ Gerber, 1990, p. 205).

Each person experiencing the picture book during the reading may interpret the text somewhat differently during the same read-aloud event, depending on prior knowledge or previous experiences with the same text. Changing performance cues or instructional cues can result in different interpretants in the minds of the children and the teacher. 
Golden and Gerber (1992) illustrated how interpretants in a sign relationship become signs in a series of significations through their analysis of children's responses to the tale of Little Red Riding Hood. Children in a second-grade class on an American Indian reservation were asked by their teacher to retell the story of Little Red Riding Hood through an oral telling, writing, or images. Earlier in the school year the children had experienced a read-aloud event with a book about Little Red Riding Hood. The object of this initial event was an idea of the tale, and the picture book read by the teacher was a sign or representamen for the tale of Little Red Riding Hood. The meanings made by the children during this initial performance were interpretants. During the second activity later in the school year, the children's responses or interpretants to the earlier reading became signs, or representamena, for new interpretants - the children's creative responses to Little Red Riding Hood (their oral retelling, written stories, and images).

Next, the children performed in front of their classmates, so their retellings and stories became signs for interpretants created in the minds of their classmates as they experienced the retellings and stories. The teacher then discussed structural elements of the text using a picture book and introduced the idea of different versions of a tale, which resulted in other interpretants in the minds of the children. These interpretants became signs for another sign relationship where children expressed this idea through stories they created with other characters, such as dinosaurs and a coyote and rabbit. One sign led to another over the course of the teacher's unit on Little Red Riding Hood, which resulted in a chain of signification related to the initial object of the idea of the tale.

Transmediation, a semiotic process where one sign system can be recast in another sign system - such as written language in a picture book being expressed as a child's drawing - was also explored by literacy researchers (Siegel, 1995). Harste, Short, and Burke (1988) developed a curricular activity called Sketch to Stretch where children were asked to draw a sketch that symbolized what a story meant to them. The focus of the strategy was on the meaning making process, not just on sketching a favorite part of the story. Berghoff, Egawa, Harste, and Hoonan (2000) explored how children made meaning using the Sketch to Stretch activity and other multimodal literacy activities in the classroom. Applying the concept of transmediation to literacy teaching and learning, they discovered that "every sign system contributes something unique to the making and sharing of meaning" and "every instance of making and sharing meaning is a multimodal event involving many sign systems in addition to language" (p. 4). They also learned that "transmediation is most powerful in a social setting" (p. 3).

Play is "a valuable semiotic system in its own right" and can foster children's multiple ways of understanding and representation (Wohlwend, 2011, p. 317). In play-literacy events when young children interact with family members or classmates, they move seamlessly between different modes of communication. For example, in a recent study by Kim and Kim (2017), a 4-year-old bilingual boy made intertextual and multimodal connections between his drawing and 
YouTube videos in Korean that resulted in a drawing-telling-performance of dinosaur extinction theories for family members. Winters (2012) documented her 6-year-old son's multimodal literacy experiences out of the classroom for three weeks one summer. In different social contexts he blended different semiotic systems of expression, including musical and embodied semiotic resources when he sang his own tune and danced to it and pictorial and linguistic semiotic resources when he read a picture book, created a comic strip, and drew a map. Intrigued by her son's use of music, Winters noted that "music has the potential to create some meanings that challenge and elude linguistic semiotic systems," especially emotional messages (p. 15).

With the coming of digital technology, multimodality and its relationship to literacy has become a focus of educational research. Kress (2003) was instrumental in expanding the definition of literacy to include communication through different semiotic modes and used the term multimodal to describe the simultaneous use of different modes. More recently, Dressman (2015) explored the effectiveness of different semiotic theories to analyze digital texts, in particular two digital news reports. He found that a Peircean-based-approach opened his analysis to the relationship among different modalities and types of signs involved in digital multimodal texts. A Peircean perspective also allowed him to define his unit of analysis, which was not possible with other approaches. Dressman learned from his application of a Peircean analytical approach that

"signs can refer to the things they represent in several different ways, that these can be precisely described, and that naming them is central to understanding how texts are apprehended, or perceived, and then comprehended, or understood." ( $p .132)$

Peirce's theories of the process of making meaning from texts can be applied to any multimodal texts, including children's texts created in a classroom context, as I have done in the present article. While semiotic theories formed the basis of some important analyses of literacy learning in the 1980s and 1990s, Peirce's theories can still provide important insights into the meanings generated from multimodal texts created and used in various learning situations, as recent studies discussed here have shown.

\section{Sign Relationships in a Kindergarten Class}

In my research on literacy learning in kindergarten classrooms, I have used Peirce's theory of signs as a foundation for understanding how sign use relates to literacy learning in classrooms. Viewing classroom literacy events in terms of a triadic relationship of object, representamen, and interpretant helps to reveal the meaning-making processes children and teachers use as they participate in these activities. In order to show how Peirce's theory of signs can be applied to analyses of classroom learning, I will use examples of literacy events in a kindergarten classroom where I carried out a qualitative yearlong case study of multimodal literacy learning. My methodology included participant observation, fieldnotes, informal interviews with the teacher and students, photographing, audio and videotaping classroom multimodal literacy events, and collecting children's writings/drawing. I was a participant observer in the 
classroom every day for the first two weeks of school, three days per week through October, and two to three days per week from then until the last day of school. Data sources included a collection of over 500 digitized children's drawings/writings, fieldnotes from September through June, transcripts of video and audio recordings of literacy activities, and transcripts of video and audio recorded interviews of children and the teacher.

The classroom teacher, Mrs. Thomas, had taught at the elementary school level for 17 years. (All names are pseudonyms.) She had been teaching kindergarten for seven years at the time of the study. During this school year there were 23 students in her kindergarten class, 13 girls and 10 boys. The school was located in the Mid-Atlantic region of the United States and drew children from suburban, urban, and rural areas of the school district. Mrs. Thomas believed it was important to keep up with the latest trends in teaching. She was knowledgeable about emergent literacy research and applied many of the ideas she learned from this research to her teaching. Inherent in an emergent literacy perspective is the idea that multimodal forms of expression are valued at the beginning of kindergarten. As children take part in classroom literacy events, their literacy development will move towards more conventional forms of literacy (Solsken, 1993; Teale \& Sulzby, 1986).

\section{Choices Drawing/Writing}

Mrs. Thomas viewed children's drawings at the beginning of the year as emergent writing. Early in the school year, she encouraged the children to draw by setting up a table with writing implements. During Choices, a time in the morning for children to explore different activities - such as playing house in a play kitchen, playing board games, building with large blocks, or "reading" from the classroom library - children could sit at the writing table and draw pictures. Mrs. Thomas also encouraged the children to talk about their drawings. She used this talk to help the children make connections between their written productions and stories or oral language productions.

By the end of the second week of school, September 17, a small group of four children - Alex, Vanessa, Amanda, and Dwight - began to go to the drawing table almost every morning during Choices. This small group gradually expanded so that the children who wanted to draw/write could no longer fit around the table. Some had to use a lapboard and sit on the rug where group activities were held. Choices drawings early in the school year primarily made connections between home and school. I observed most of the children drawing a house on at least one occasion. On October 1, Vanessa drew a house. Karen and Jeanine, who were sitting next to her, saw her drawing. Vanessa told her friends, "I'm drawing a house." Her friends began to draw houses on their papers. As Karen drew, she asked Vanessa to show her how to make windows. On October 20, Vanessa drew another house while seated at the drawing table. Figure 1 shows this drawing. Vanessa talked to me as she was drawing her house.

Vanessa: That's my house. (pointing to the house on her paper)

Researcher: What's around the house? (no response) 
What's this and this and this? (pointing to what looks like windows) Vanessa: It's windows.

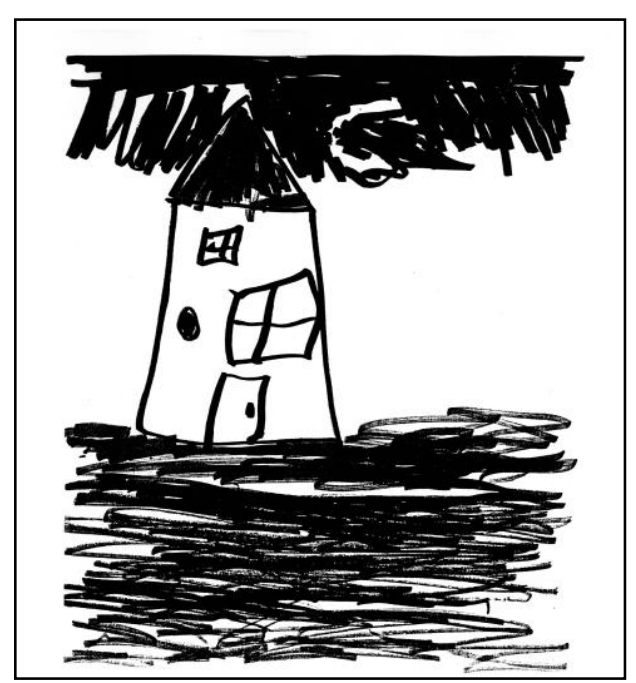

Figure 1: Vanessa's House Drawing

Vanessa's drawing of a house can be seen as a sign, or representamen, in a triadic sign relationship as conceived by Peirce. This sign exists within the social context of Mrs. Thomas's kindergarten classroom. Although "single signs do not exist [and] their very existence presupposes other signs" (Siegel, 1984), for purposes of analysis I will start by looking at a single triadic sign (see Figure 2).

Vanessa told me her drawing was of her house, so the object of her drawing, what she intended to represent, is her own house. The meaning she expressed by producing this drawing may be the sense of security she feels at home with her family, or it may be a way to connect with other classmates. She may be thinking of her home and drew a picture of a house to represent this feeling. Any of these meanings could be interpretants of her drawing. The ground would be the window shapes and pointed roof, characteristics of the drawing that distinguish the visual image as a house. 


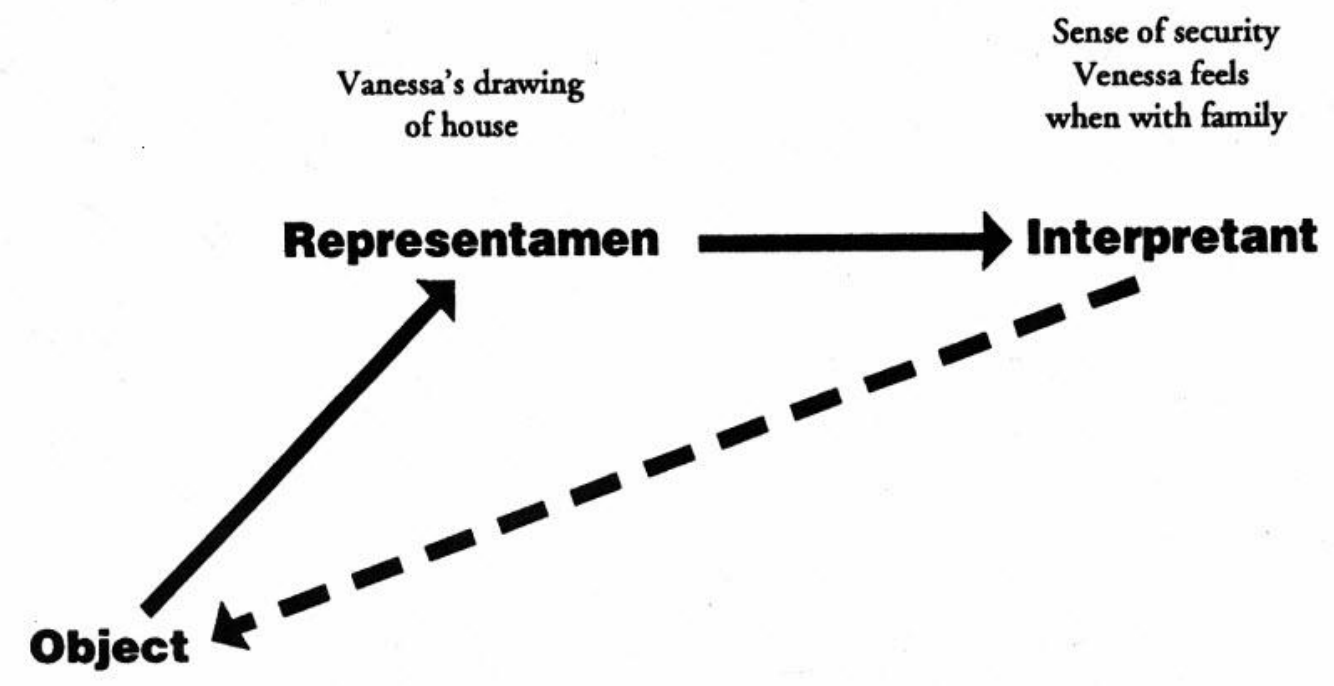

Vanessa's actual house

Figure 2: Triadic Sign of Vanessa's Drawing

When Mrs. Thomas views Vanessa's drawing, she sees Vanessa is beginning to express her ideas in the classroom through visual images. That is an interpretant in the mind of the classroom teacher. The writing table Mrs. Thomas set up is also a sign representing the emergent literacy theory that values children's drawings as a stage of early writing development. Another object of the writing table is Mrs. Thomas's belief that children become better writers if they are given opportunities to socialize and talk about their drawings. Vanessa's first drawing led to her friends' interpretants, their own drawings of houses. They interpreted Vanessa's sign by creating signs of their own that were similar to hers. As they talked about their drawings, they created other triadic sign relationships, with spoken language serving a symbolic function.

Janice also drew a picture of a house on October 20, but her object and interpretant were different than Vanessa's. I had the following interview with Janice about her drawing.

Janice: There's a house and that's a tree (pointing to the visual forms on her paper).

Researcher: Is that a special house that you drew? Or just one in your mind? (no response) Or is that your house or somebody's house you've been to? Or just a house?

Janice: Your house.

Researcher: You drew MY house?

Janice: (shakes head "yes")

Researcher: Oh. And that's a tree by my house? What color is my house?

Janice: I just drew it brown. 
Researcher: Yeah. You just made a house. Any house.

Janice: (shakes head "yes")

Researcher: Do you like to draw houses? Are they your favorite thing to draw?

Janice: (shakes head "yes")

Researcher: Oh, how nice.

Janice: Sometimes I like to draw some other stuff.

Researcher: What else do you like to draw?

Janice: I like to draw um ducks, horses, and dogs and cats.

The object of the house and tree Janice had drawn was my house; however, she had never seen my house, so she imagined a generic house that was brown. The interpretant is the meaning she expressed through her drawing - a show of friendship and of a personal connection to me. When I first saw her picture, I thought it was a drawing of her house, so the interpretant I created was a mental image of Janice's house. Other interpretants of sign relationships created by my own mind were my ideas that the children liked to draw houses, that drawing houses helped the children make home-school connections, and that drawing houses at the writing table helped children to make friends. When Janice interpreted her drawing with the words "Your house," a new sign relationship formed with new interpretants. One interpretant could be that Janice did not know the object of her drawing, so she made up an explanation that she was drawing my house. Another interpretant could be that Janice wanted to show me she was my friend. I was Mrs. Thomas's classroom "helper," so she may have been exploring my role in the classroom.

Just as the meaning of signs evolved in the children's sketches in the fourth-grade class studied by Siegel (1984), the meaning of house drawings evolved during Choices writing activities in Mrs. Thomas's classroom. At first the children drew pictures to represent their own homes and the interpretant was making connections between home and school. Then, as more children joined in the drawing of houses, the pictures of houses became a show of friendship. In the evolution of the use of house drawings during Choices, a series of triadic sign relationships developed, with the sign elements shifting roles. This demonstrates Peirce's idea of semiosis as an "infinite process" or an "endless series" (Peirce, cited in Parmentier, 1985, p. 29).

While individual sign relationships and a series of relationships can be removed from the social context for purposes of analysis, a more authentic representation of sign use would place sign relationships within social contexts. Peirce's (1955) notion of triadic sign relationships can be 
used to explain sign use in more complex social relationships. In Mrs. Thomas's kindergarten class, the children's drawings of houses fit into a broader classroom context. During Choices the children also drew pictures of family members, friends, and holiday symbols, such as pumpkins, as well as houses. The objects of their drawings evolved to include making home to school connections and developing friendships. The interpretants created from the drawings included feeling comfortable at school among classmates and sharing home life with their teacher and friends. These representations have more than one object and interpretant, which fits into Peirce's theory. He noted in a draft of Toward a Logic Book (1873/1986a) that a sign can be "applicable to more than one possible object" (p. 84). Opening up the triadic sign relationship by allowing for more than one object, and more than one interpretant, makes Peirce's theory applicable to complex semiotic events in social settings. Figure 3 shows a possible way of interpreting the sign relationships represented by the kindergarten children's Choices drawings.

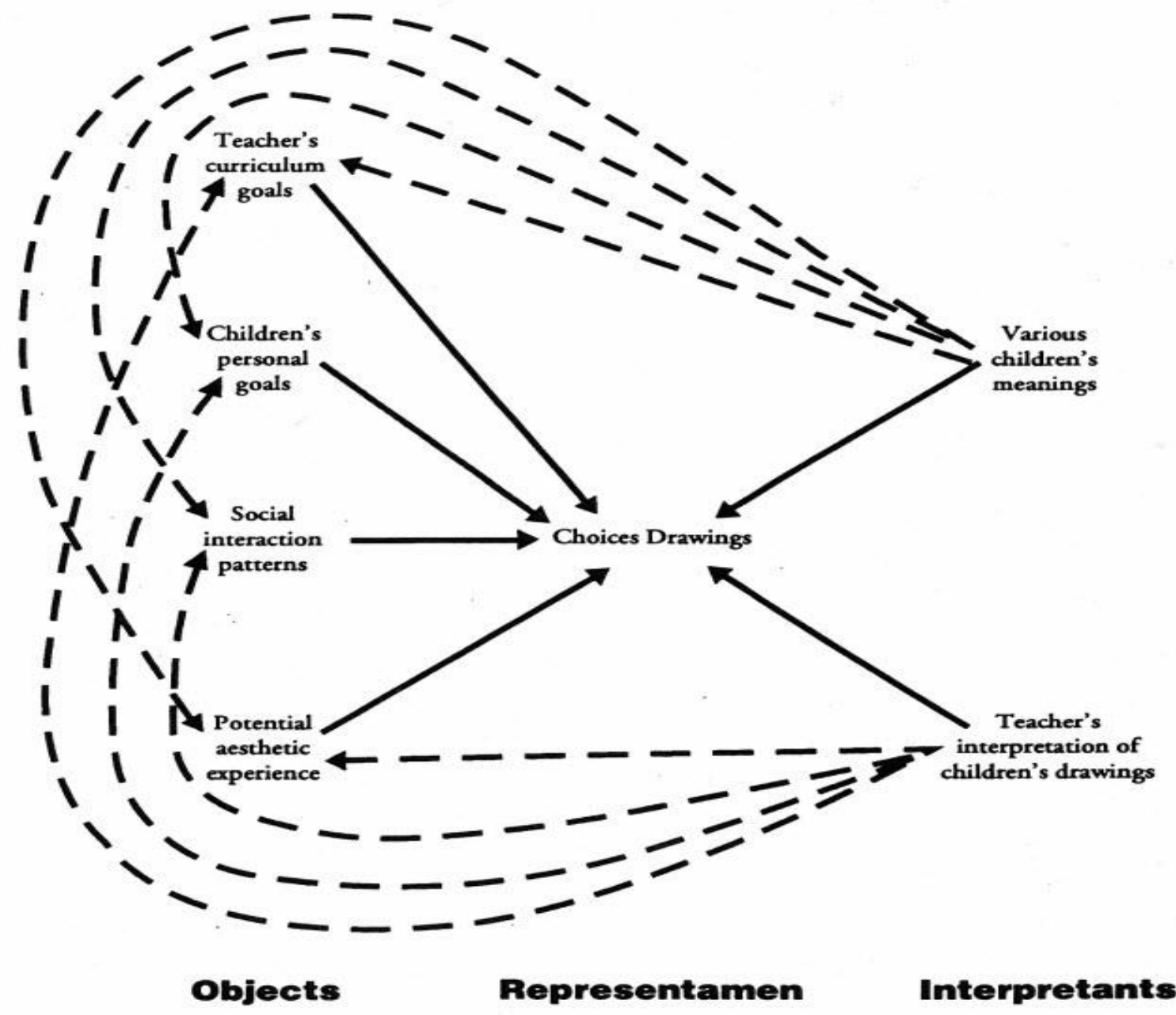

Figure 3: Semiotic Relationships of Drawings during Choices 
The semiotic relationships just represented can be placed within an even wider social framework. Drawing during Choices is one type of literacy event that takes place in Mrs. Thomas's kindergarten classroom. The children's drawings may represent a number of objects - the teacher's curriculum goals, the individual children's personal goals, patterns of classroom social interaction, and the potential aesthetic experience of the children creating texts. Each child makes his or her own meaning from the event, so different interpretants exist for the various children although some children may have the same interpretant. The teacher "reads" the children's drawings/writings in certain ways. The interpretant representing her meaning may be different from the interpretants representing the children's meanings. Figure 4 illustrates these sign relationships.

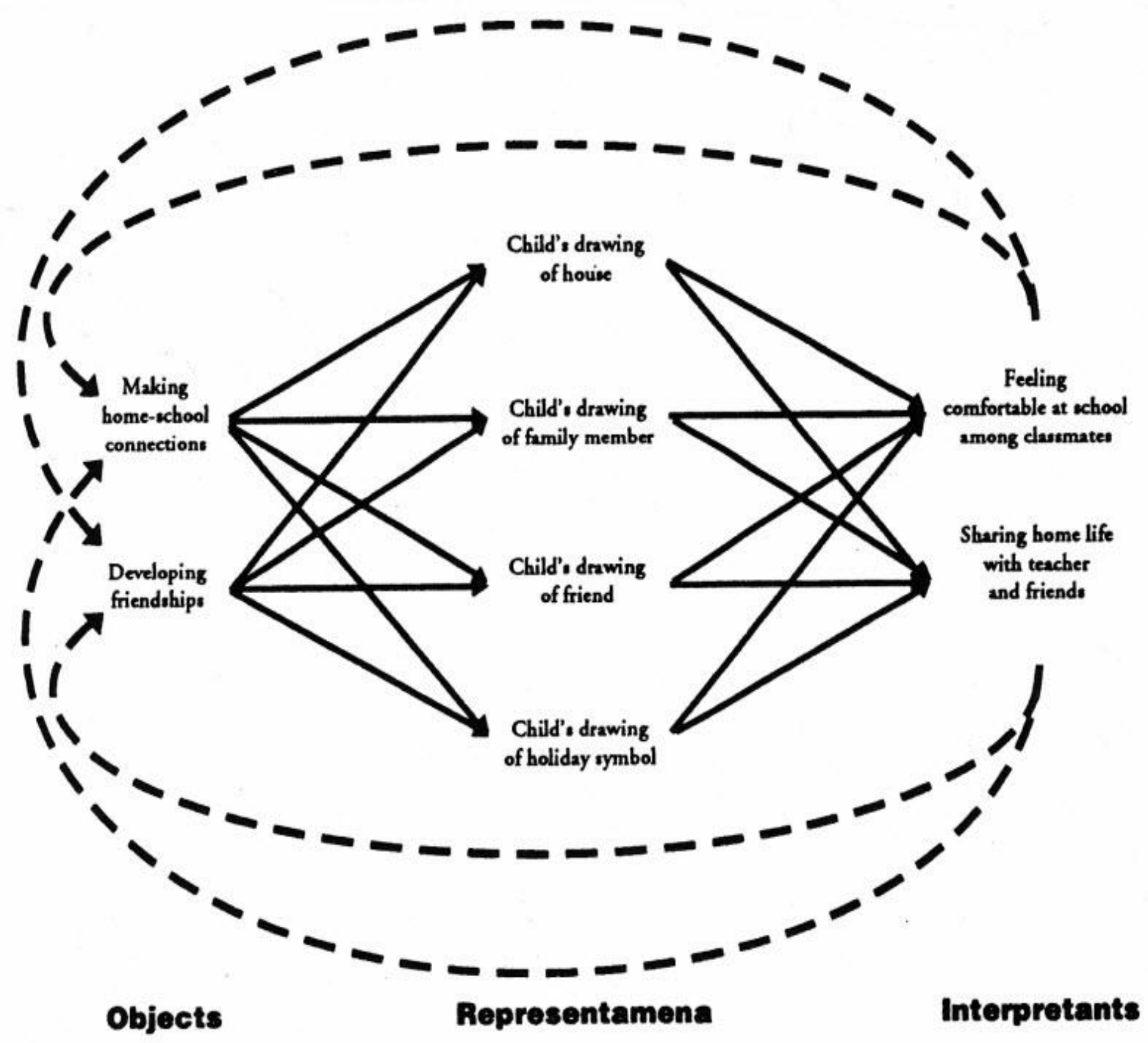

Figure 4: Semiotic Relationships of Children's Drawings 
While most Choices drawings were about personal experiences, some children experimented with making shapes and designs. On September 28 , Sally showed me a brightly colored picture she had made. When I asked her to tell me about her picture, she said she had not made anything special: "I

just took different colors and made lines and dots." The object of Sally's drawing was experimentation with colors and shapes, and her interpretant was the colored lines and dots she put on her paper. Other children made drawings/writings about topics discussed during Group Time or picture books read-aloud to the class. Some children like Marjorie created oral texts about the fire safety theme. On September 22, she told me the story she had just drawn:

When the fire blocked, blocked my door um I couldn't get out but I got, but I cutted my door with one of my cutter toys, and when I got the, my my play water hose thingy and I squirted it all out and I was all safe.

\section{Other Forms of Emergent Writing}

The patterns of social interaction developing during Choices drawing time prepared the children for Writer's Workshop activities later in the year. While Mrs. Thomas more formally molded the children into a community of learners during group storybook readings, she allowed the children to gradually and informally build their own supportive writing community. In October, Mrs. Thomas introduced the children to a new form of writing she called Word Book. Word Books were a type of journal adapted to the developmental level of kindergartners. For each entry in their Word Book, children were asked to think of a story they wanted to "write," a picture they could draw about the story, and a word that went with the story. Choices drawings were a transition to Word Book writing. Mrs. Thomas wrote the children's words on an index card, and the children copied their word onto their Word Book page. As children transitioned to creating this type of multimodal sign, most children drew their picture first and then copied the word from the card. When Mrs. Thomas asked them to tell their stories, they told a few sentences such as, "This is my cat." Or "I went to Sea World and saw a dolphin."

The interpretants for the Word Book entries changed as the children became more experienced at "writing" in their multimodal journals. If we start with the house drawings children created during Choices, as in Figure 1, and view these drawings as the first interpretant in a series of signs, we can follow the use of houses in Word Book entries throughout the school year and see the changing interpretants. When children became more familiar with Word Book writing, houses became a setting in their stories, as in Sally's Word Book entry about her cat in Figure 5. Sally drew a cat inside a house and wrote the word CAT to the right of her drawing of the house. The interpretant for this Word Book page is Sally's developing concept of story, which included a setting. 


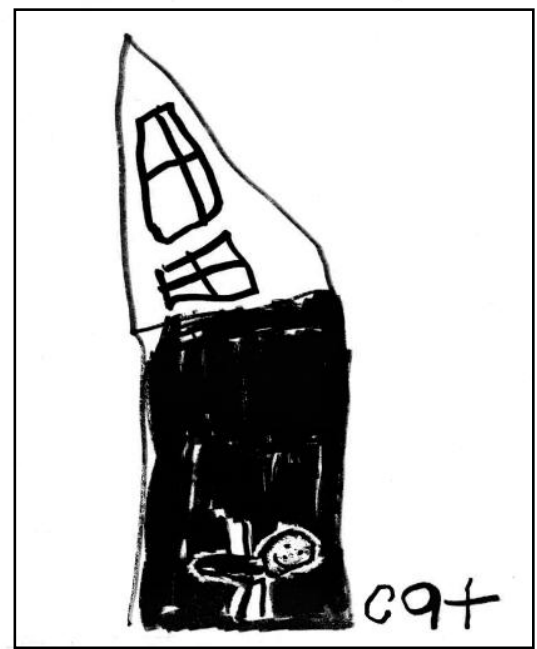

Figure 5: Sally's Cat Story

Jeanine's entry for her Halloween story in Figure 6 shows her focus on matching printed words to visual images of individual objects in her story, including a house. She labels the objects in her story, copying the words from the word cards she collected. The interpretant resulting in the teacher's mind is Jeanine's growing understanding of print concepts. The interpretant in Jeanine's mind is her understanding that printed words can be matched with visual representations of objects.

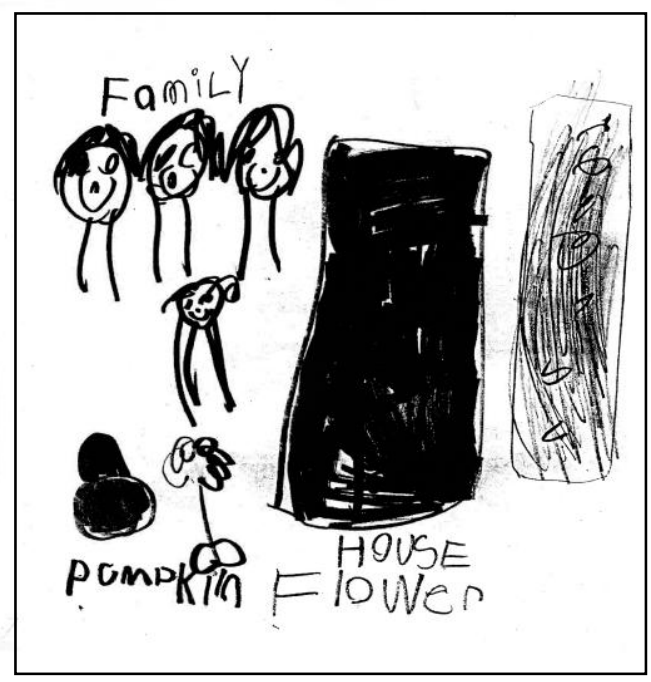

Figure 6: Jeanine's Halloween Story

In Figure 7, Katha writes a story about her house, so house becomes the theme of her story, and HOUSE is the primary word needed to tell the story. In the upper right-hand corner of the page, Katha uses invented spelling to "pretend" write her story, while her illustration visually shows the apartment building where she lived. One interpretant is Katha's understanding that letters represent spoken words in stories. Mrs. Thomas noticed that the letters Katha wrote did not phonetically match real words in her story, so the interpretant in Mrs. Thomas's mind was Katha's developmental stage of writing strings of letters rather than phonetically similar invented spelling. At this point in the school 


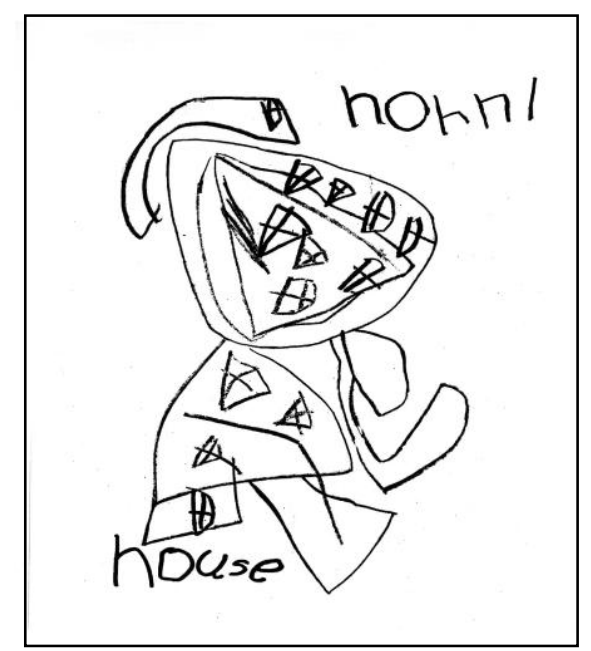

Figure 7: Katha's House Story

year, children began to focus on representing characters and events from picture books Mrs. Thomas read aloud to her class or from television programs. Houses in Word Book drawings, then, were primarily used by the children as settings for their stories.

\section{Conclusion}

Within kindergarten classrooms, picture books, children's journals, and dramatic performances are all multimodal signs. Each of these signs is composed of other signs, such as printed or spoken words, gestures, or pen and ink drawings. The entire multimodal sign, such as a picture book, may lead to an interpretant - a visualized and mentally verbalized version of a folktale or a feeling of being part of a community of learners. A single sign that is a part of the multimodal sign - a watercolor illustration of a butterfly, the teacher's pointing to the printed words as she reads, a child's comment to his friend as he writes in his journal - also results in interpretants. All of these signs and the interpretants they give rise to together make up the text of the literacy event. Each multimodal sign "has the potential to participate in any number of texts by virtue of its mediations by an interpretant" (Siegel, 1984, p. 55).

As children develop their literacy skills throughout the school year, the objects and interpretants of the signs they create or the signs they experience through the teacher's curriculum change. At the same time, different participants may interpret events and representations in different ways, which results in multiple interpretants for the same representamen. Peirce's concept of triadic sign relationships with an unlimited variety of forms makes it possible to explore the various meanings children and their teachers create and respond to in kindergarten classrooms where multimodal forms of expression are celebrated and welcomed.

As a literacy researcher in a kindergarten classroom, I looked around me and saw many signs related to multimodal literacy learning. With each sign, I asked, 
"How is this sign being interpreted - by the teacher, by individual students, and by groups of students?" and "What is the object of this sign?" Some of the objects could easily be inferred, but other objects could only be uncovered by interviewing participants; however, once a participant discussed a sign, another dimension was added to the sign relationship since verbal language was interpreting the sign even further. Peirce's idea that a representation can have more than one object and interpretant opened my eyes to the potential of using his theory of signs to understand what I was observing in kindergarten classrooms. His idea of sign relationships as an endless series relates in my mind to developmental changes to children's use and interpretation of signs. Peirce's triadic theory of signs provides a way to analyze classroom events in their full semiotic complexity.

\section{References}

Berghoff, B., Egawa, K. A., Harste, J. C., \& Hoonan, B. T. (2000). Beyond reading and writing: Inquiry, curriculum, and multiple ways of knowing. Urbana, IL: National Council of Teachers of English.

Brent, J. (1993). Charles Sanders Peirce, A life. Bloomington: Indiana University Press.

Buczynska-Garewicz, H. (1981). The interpretant and a system of signs. Ars Semiotica: An International Journal of Semiotics, 4, 187-200.

Calkins, L. M. (1980). Children's rewriting strategies. Research in the Teaching of English, 14, 331-341.

Clancy, W. J., \& Roschelle, J. (1991, April). Situated cognition: How representations are created and given meaning. Paper presented at the American Educational Research Association Annual Meeting, Chicago, IL.

Colapietro, V. M. (1993). Glossary of semiotics. New York: Paragon House.

Danesi, M. (1993). Messages and meanings: An introduction to semiotics. Toronto: Canadian Scholars' Press.

Dressman, M. (2015). Reading as the interpretation of signs. Reading Research Quarterly, 51, 111-136. doi:10.1002/rrq.114

Dyson, A. H. (1982a). The emergence of visible language: Interrelationships between drawing and early writing. Visible Language, 6, 360-381.

Dyson, A. H. (1982b). Reading, writing, and language: Young children solving the written language puzzle. Language Arts, 59, 829-839.

Eco, U. (1976). A theory of semiotics. Bloomington: Indiana University Press.

Golden, J. M., \& Gerber, A. (1990). A semiotic perspective of text: The picture story book event. Journal of Reading Behavior, 22, 203-219. https://doi.org/10.1080/10862969009547707

Golden, J. M., \& Gerber, A. (1992). The sign of a tale: The literary symbol in a classroom context. Semiotica, 89(1/3), 35-46. https:// doi.org/10.1515/semi.1992.89.1-3.35

Harste, J., Short, K., \& Burke, C. (1988). Creating classrooms for authors: The reading-writing connection. Portsmouth, NH: Heinemann Publishers.

Kim, K., \& Kim, K. (2017). Multimodal play-literacy: A preschooler's storytelling, drawing, and performing of dinosaur extinction theories. Early Child Development and Care, 187, 568-582. doi:10.1080/03004430.2016.1225044

Kress, G. (2003). Literacy in the new media age. London, Routledge.

Merrell, F. (1995). Peirce's semiotics now: A primer. Toronto: Canadian Scholars' Press.

Parmentier, R. J. (1985). Signs' place in medias res: Peirce's concept of semiotic mediation. In E. Mertz E \& R. J. Parmentier (Eds.), Semiotic mediation: Sociocultural and psychological perspectives (pp. 23-48). Orlando: Academic Press. https://doi.org/10.1016/b978-0-12-491280-9.50008-x 
Peirce, C. S. (1955). Logic as semiotic: The theory of signs. In J. Buchler (Ed.), The Philosophy of Peirce: Selected writings (pp. 98-119). London: Routledge \& Kegan Paul.

Peirce, C. S. (1873/1986a). Chap. 9th: Toward a Logic Book, MS 223: March 15, 1973. In C. J. W. Kloesel (Ed.), Writings of Charles S. Peirce: A chronological edition Vol. 3 (pp. 98119). Bloomington: Indiana University Press.

Peirce, C. S. (1986b). On representations: Toward a logic book, MS 213: Winter-Spring 1973. In C. J. W. Kloesel (Ed.), Writings of Charles S. Peirce: A chronological edition Vol. 3 (pp. 65-66). Bloomington: Indiana University Press.

Rowe, D. W. (1994). Preschoolers as authors: Literacy learning in the social world of the classroom. Cresskill, NJ: Hampton Press.

Siegel, M. G. (1984). Reading as signification. PhD Thesis, Indiana University, Bloomington, IN. Ann Arbor, MI: University Microfilms International (Publication No. AAT 8429377; ProQuest Document No. 749455141)

Siegel, M. (1995). More than words: The generative power of transmediation for learning. Canadian Journal of Education, 20, 455-475. https://doi.org/10.2307/1495082

Solsken, J. W. (1993). Literacy, gender, \& work in families and in school. Norwood, NJ: Ablex.

Sulzby, E. (1985a). Children's emergent reading of favorite storybooks: A developmental study. Reading Research Quarterly, 20, 458-481. https://doi.org/10.1598/rrq.20.4.4

Sulzby, E. (1985b). Kindergartners as writers and readers. In M. Farr (Ed.) Advances in writing research, Vol. 1: Children's early writing development (pp. 127-199). Norwood, NJ: Ablex.

Sulzby, E., Barnhart, J., \& Hieshima, J. (1989). Forms of writing and rereading from writing: A preliminary report. In J. Mason (Ed.), Reading and writing connections (pp. 31-63). Needham Heights, MA: Allyn \& Bacon.

Teale, W. H., \& Sulzby, E. (Eds.). (1986). Emergent literacy: Writing and reading. Norwood, NJ: Ablex.

Whitson, J. A. (1997). Cognition as a semiotic process: From situated mediation to critical reflective transcendence. In D. Kirshner \& J. A. Whitson (Eds.), Situated cognition: Social, semiotic, and psychological perspectives (pp. 97-149). Mahwah NJ: Erlbaum.

Winters, K-L. (2012). The missing tooth: Case illustrations of a child's assembled, out-ofschool authorship. Brock Education: A Journal of Educational Research and Practice, 22(1), 3-25. doi:https://doi.org/10.26522/brocked.v22i1.304

Winters, K-L., \& Vratulis, V. (2013). Authored assemblages in a digital world: Illustrations of a child's online social, critical and semiotic meaning-making. Journal of Early Childhood Literacy, 13, 529-554. doi:10.1177/1468798412438752

Wohlwend, K. (2011). Mapping modes in children's play and design: An action-oriented approach to critical multimodal analysis. In R. Rogers (Ed.), An introduction to critical discourse analysis in education (2nd ed., pp.242-266). Mahwash, NJ: Erlbaum.

Zhang, K., Djonov, E., \& Toor, J. (2016). Reading and reinterpreting picture books on children's television: Implications for young children's narrative literacy. Children's Literature in Education, 47, 129-147. doi:10.1007/s10583-015-9259-x 